\title{
Vaksin Human Chorionic Gonadotropin (hCG) sebagai Kandidat Kontrasepsi Imunologi pada Wanita
}

\section{Human Chorionic Gonadotropin (hCG) Vaccine as a Women Immunological Contraception Candidate}

\author{
Darmawi $^{1}$ \\ ${ }^{1}$ Kelompok Jabatan Fungsional Histologi, Fakultas Kedokteran Universitas Riau
}

\begin{abstract}
ABSTRAK
Tercatat pada tahun 2017 ada sekitar 7,5 miliar jumlah populasi manusia dengan angka pertumbuhan 1 miliar setiap 12 tahun. Peningkatan populasi ini terjadi $95 \%$ di negara berkembang. Setiap tahun ada sekitar 80 juta wanita di seluruh dunia setiap tahunnya mengalami kehamilan yang tidak diinginkan dan sebagian besar wanita pada kelompok ini menggunakan beberapa metode kontrasepsi yang telah tersedia. Oleh karena itu, diperlukan metode kontrasepsi baru dan lebih baik yang dapat diterima, efektif, dapat dijangkau dan tersedia diberbagai negara berkembang, yaitu dengan metode kontrasepsi imunologi. Salah satu metode kontrasepsi imunologi pada wanita adalah vaksin hCG. Vaksin hCG ini pertama kali dipublikasikan oleh Talwar, et al pada tahun 1976 dan menjadi satu-satunya metode kontrasepsi imunologi yang telah melewati uji klinis fase II. hCG merupakan target potensial dan terbaik dalam mencegah kehamilan tanpa adanya efek samping yang merugikan. Berbeda dari kontrasepsi steroid yang dapat menghambat ovulasi, metode vaksin hCG tidak menganggu ovulasi dan produksi hormon steorid seks serta tidak menganggu keteraturan siklus menstruasi. Baik protein ujung C (CTP) dari $\beta$-hCG maupun $\beta$-hCGnya sendiri telah digunakan sebagai kandidat imunogen untuk mengembangkan kontrasepsi imunologi. Metode ini diketahui aman, efektif menekan angka kehamilan dan bersifat reversibel.
\end{abstract}

Kata kunci: Kontrasepsi imunologi, Vaksin, hCG

\begin{abstract}
In 2017, there are about 7.5 billion human population with growth rate average in 1 billion each 12 years. This is occurs $95 \%$ in developing countries. Annualy, Wordwide, there are about 80 million women deal with unintended pregnancies and most of this women are the users of the available current contraceptive method. Thus, undoubtedly, we need the newest, better, effective, economical, acceptable and easily available contraceptive methods, immunological contraceptive is one of the solution. One of the immunological contraceptive in women is hCG vaccine. It was proposed by Talwar et all in 1976 and have been the one and only underwent phase II clinical pharmacological trials. $h C G$ is a promising and the best targeted molecule to prevent pregnancy without any harmfull side effect. By this method, distinct from steroid contraceptive, there are no affect on ovulation, sex steroid production and menses cycle in women. Both C terminal protein (CTP) of B-hCG and B-hCG have been used immunogenically as a candidate in developing immunological contraceptive. This method was evidently safe, effective in inhibiting pregnancy and reversible fertility.
\end{abstract}

Keywords: Immunological contraceptive, Vaccine, $h C G$

Korespondensi : Darmawi, email: darmawi@lecturer.unri.ac.id

Artikel info: Online published first 14 September 2017.

DOI: https://doi.org/10.26891/jkm.v1i1.2017.29-34

Copyright @ 2017 Authors. This is an open access article distributed under the terms of the Creative Commons Attribution-NonCommercial 4.0 International License (http://creativecommons.org/licenses/by-nc/4.0/), which permits unrestricted non-commercial use, distribution, and reproduction in any medium, provided the original author and source are properly cited. 
Vaksin telah digunakan secara luas untuk meningkatkan pertahanan imunitas melawan berbagai penyakit infeksi, seperti difteri, pertusis, tetanus, poliomyelitis, measles, hepatitis dan lain-lain. Selanjutnya, sekarang sedang ada usaha untuk mengembangkan vaksin terapeutik untuk mengobati kanker, penyakit autoimun dan penyakit lainnya. ${ }^{1,2}$ Sebagai contoh, untuk mengobati simptomatik atau minimal simptomatik kanker prostat metastatik yang sangat responsif terhadap hormon. Pengobatan ini dengan Sipuleucel- $T$, produksinya melibatkan isolasi sel antigen presenting cell (APC)/dentritik pasien lalu diinkubasi dengan asam fosfat prostat dan granulocyte-macrophage colony stimulation factor (GM-CSF), dilanjutkan dengan menginfuskan APC yang telah aktif tadi ke pasien. ${ }^{3}$ Selain itu dengan adanya penggunaan vaksin untuk penyakit autoimun, seperti Chrohn's disease, rheumatoid arthritis, dan diabetes tipe-1 dan lain-lain, melibatkan vaksinisasi dengan protein atau peptida self untuk meninduksi toleransi. $^{2}$

Peningkatan populasi manusia terutama pada sebagian besar negara berkembang di benua Asia dan Afrika. Hal ini menyebabkan gangguan pada lingkungan dengan adanya pengurangan sumber daya alam, kelangkaan air minum serta ancaman keamanan dan kelangkaan makanan. ${ }^{4}$ Jumlah polpulasi dunia pada bulan April tahun 2017 berjumlah 7,5 miliar dan terus meningkat (http://www.worldometers.info/world-population)

sehingga diperkirakan pada tahun 2046 jumlah populasi manusia di dunia adalah 9 miliar orang. ${ }^{5}$ U.S Census Bureau mencatat adanya peningkatan sebanyak 1 miliar populasi manusia tiap 12 tahunnya dengan angka kelahiran tiap hari di dunia adalah kurang lebih 270.000 orang dan 95\%-nya terjadi pada negara berkembang. ${ }^{6}$ Data dari WHO pada tahun 2011 menunjukkan ada sekitar 80 juta wanita di seluruh dunia setiap tahunnya mengalami kehamilan yang tidak diinginkan dan sekitar 45 juta diantaranya melakukan aborsi elektif. ${ }^{7}$ Data di Amerika menunjukkan setengah angka kehamilan setiap tahunnya adalah kehamilan yang tidak diinginkan dan sebagian besar wanita pada kelompok ini menggunakan beberapa metode kontrasepsi, antara lain pil kontrasepsi oral mengandung hormon steroid, implant, intrauterine devices (IUD) dan kondom baik pria maupun wanita. ${ }^{8}$ Melihat hal tersebut, para peneliti berfikir bahwa diperlukan metode kontrasepsi baru dan lebih baik yang dapat diterima, efektif dan tersedia diberbagai negara berkembang, salah satunya dengan metode kontrasepsi vaksin. Kontrasepsi vaksin telah dilaporkan memiliki efektifitas yang tinggi untuk menekan populasi hewan liar, seperti anjing, kucing, gajah, kangguru dan lain-lain. Ada beberapa metode kontrasepsi vaksin yang dilaporkan memiliki peluang besar dalam keberhasilan mencegah kehamilan yang tidak dinginkan dan menekan populasi, yang pada akhirnya dapat meningkatkan kesejahteraan dan kesehatan masyarakat. ${ }^{9}$

Kontrasepsi vaksin dikategorikan menjadi 3 kelompok. Kelompok pertama bertujuan menghambat pembentukan gamet (spermatozoa dan oosit). Vaksin ini bekerja dengan menghambat kerja gonadotropin releasing hormone $(\mathrm{GnRH})$ yang dilepaskan oleh hipotalamus. GnRH berperan baik pada sistem reproduksi pria maupun wanita dengan bekerja pada kelenjar hipofisis anterior, menstimulasi pelepasan luteinizing hormone (LH) dan follicle stimulating hormone (FSH). FSH memiliki peran dalam perkembangan dan maturasi dari folikel ovarium pada wanita dan spermatogenesis pada pria. LH berperan penting dalam steroidogenesis baik pada pria dan wanita serta ovulasi pada wanita. Netralisasi kerja LH dan FSH serta reseptornya dengan mediasi sel imun dapat menyebabkan penghambatan gametogenesis. Kelompok kedua adalah vaksin yang memfasilitasi respon imun terhadap protein spesifik spermatozoa atau oosit, dengan tujuan menganggu fungsinya dan menghambat fertilisasi. Kelompok ketiga yaitu yang menargetkan human chorionic gonadotropin (hCG), bertujuan menganggu konsepsi untuk berimplantasi. hCG disintesis dan dilepaskan setelah terjadi fertilisasi oleh blastosis yang sedang berkembang, yang berperan dalam mempertahankan konsepsi. ${ }^{4}$

Salah satu kontrasepsi vaksin yang dapat menjadi pilihan yang ideal adalah kontrasepsi vaksin kelompok ketiga, menargetkan hCG. Vaksin ini pertama kali dipublikasikan oleh Talwar, et al (1976) dan menjadi satu-satunya metode kontrasepsi vaksin pada wanita yang telah memasuki uji klinik fase II. Vaksin ini memiliki kelebihan dapat mencapai efektifitas $90 \%$ dengan titer antibodi $50 \mathrm{ng} / \mathrm{ml}$ tanpa mengganggu ovulasi dan siklus menstruasi. Selain itu, vaksin hCG ini dilaporkan aman dan memiliki reversibilitas yang tinggi. ${ }^{10}$

Pada tinjauan pustaka ini akan dibahas tentang konsep kontrasepsi vaksin secara umum, aspek biologi hCG, perkembangan penelitian tentang pengembangan vaksin hCG untuk kontrasepsi, mekanisme kerja, dosis dan cara pemberian, efektifitas, keamanan, efek samping dan reversibilitasnya.

\section{Konsep umum vaksin kontrasepsi}

Prinsip utama kontrasepsi vaksin adalah bagaimana mengembangkan metode kontrasepsi yang dapat mencetuskan respon imun humoral dan atau seluler terhadap suatu antigen pada sistem reproduksi. Kontrasepsi vaksin ini dibuat sedemikian rupa untuk dapat menghambat; (1) produksi gamet (permatozoa dan oosit), (2) fungsi gamet (menghambat fertilisasi), dan (3) hasil akhir gamet (kehamilan). Ketiga kelompok itu merupakan target pengembangan kontrasepsi vaksin saat ini (Gambar 1). .11 Penggunaan vaksin ini dapat menjadi pilihan untuk memenuhi kebutuhan dunia baik pada negara maju maupun negara berkembang dalam hal mengontrol populasi. Kontrasepsi vaksin menjadi menarik karena faktor produksi yang ekonomis, mudah digunakan, diterima, reversibitas tinggi, kegagalan rendah dan bebas dari peralatan mekanis atau hormon eksogen serta adanya infrastruktur yang memadai dalam imunisasi massa. ${ }^{9}$ 
Spermatozoa merupakan target pertama dalam pengembangan kontrasepsi secara imunologi pada tahun 1899 oleh peraih nobel Landsteiner dari Austria dan Metnikoff dari Russia yang mengobervasi terbentuknya antibodi terhadap injeksi sperma, yang pada awal tahun 1900 peran antibodi ini pada infertilitas dilaporkan. Pada tahun 1937, Morris J. Baskin seorang ahli bedah dari Denver mematenkan vaksin spermotoxic yang dapat menginduksi sterilisasi reversibel pada wanita subur. ${ }^{12}$ Setelah itu, hanya sebagian kecil dilaporkan studi dengan menggunakan sperma banteng untuk menginduksi antibodi sperma manusia pada wanita dalam kontrasepsi. Diantara tahun 1950 sampai 1970, penelitian imunisasi sperma didorong untuk mengatur angka fertilitas. Namun, pada tahun 1970-an, para peneliti mulai mencari target lain selain sperma yang dapat dikembangkan untuk kontrasepsi vaksin. Berbagai molekul telah sedang di gali untuk pengembangan kontrasepsi vaksin (Gambar 1). ${ }^{9}$

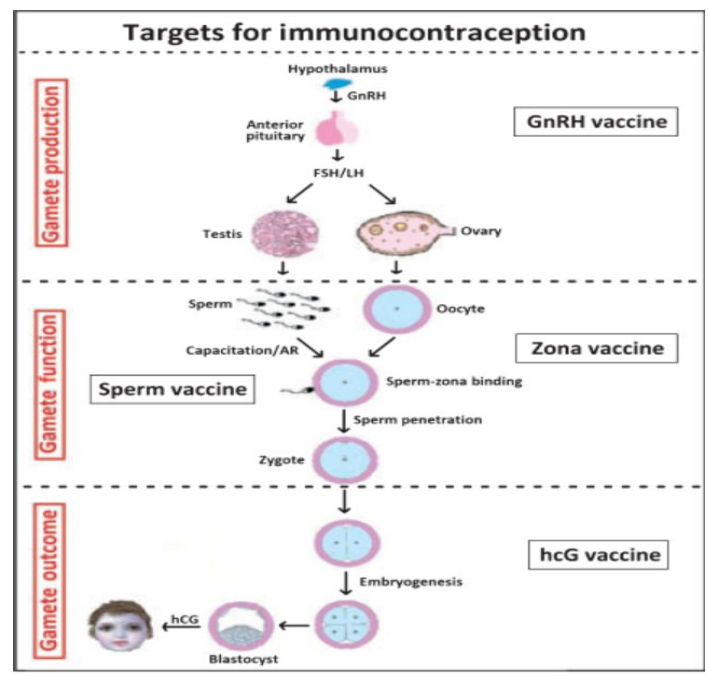

Gambar 1. Target kontrasepsi vaksin. ${ }^{9}$

Kontrasepsi vaksin yang menargetkan fungsi gamet, disebut dengan vaksin $\mathrm{GnRH}$ telah dilaporkan memiliki angka keberhasilan yang tinggi pada sebagian besar spesies hewan liar, seperti kucing baik jantan maupun betina. Vaksin ini berefek pada hormon steroid sex karena dapat menghambat pelepasan LH/FSH. Vaksin GnRH telah dikembangkan oleh berbagai perusahaan obat ditujukan untuk melakukan kastrasi pada hewan peliharaan domestik, kebun dan hewan liar. Vaksin ini dapat juga diterapkan pada manusia khususnya untuk tujuan nonkontrasepsi, seperti menekan androgen pada hipertropi dan kanker prostat pada pria serta dapat diberikan pada wanita yang memerlukan penekanan hormon steroid seperti fibrosis uterus, polycystic ovary syndrome (PCOS), endometriosis dan pubertas prekok. $^{9}$

Kontrasepsi vaksin yang menargetkan fungsi gamet, seperti antigen spermatozoa dan protein zona pellucida (ZP), adalah pilihan yang menarik. Protein spermatozoa memiliki harapan yang paling baik dan menarik dalam pengembangannya sebagai target kontrasepsi vaksin.
Dalam hal ini, beberapa antigen spermatozoa yang spesifik telah ditemukan dan dikembangan pada berbagai labortatorium. Fokus penelitiannya adalah menemukan epitop yang spesifik, memiliki imungenisitas tinggi, dan efektif untuk menekan fertilitas sebagai vaksin. Imunoinfertilitas pada anti-sperm antibody (ASA) secara natural menyediakan informasi tentang model bahwa vaksin dapat bekerja pada sistem reproduksi manusia. Vaksin yang menargetkan protein ZP dilaporkan memberikan efek samping berupa ooporitis akibat menganggu hormon steroid sex pada berbagai spesies. Vaksin ini sukses dalam mengontrol berbagai populasi hewan liar seperti kijang, kuda, gajah dan beberapa spesies hewan kebun binatang serta anjing wanita. ${ }^{9}$

Kontrasepsi vaksin yang menargetkan hasil gamet/embrio secara umum fokus pada molekul hCG. Vaksin hCG adalah vaksin yang pertama melewati uji klinis tahap I dan II pada manusia. Vaksin ini telah menunjukkan baik efektifitas dan rendahnya kondisi patologi akibat vaksin. Pada saat ini, penelitian berfokus pada meningkatkan imunogenisitas dan efektivitasnya dan meneliti aplikasinya pada beberapa kanker yang memproduksi hCG sendiri. $4,9,11$

\section{Aspek biologi hCG}

Hormon hCG terdiri dari subunit alfa $(\alpha)$ dan subunit beta $(\beta)$. Subunit $\alpha$ hCG adalah sama dengan subunit $\alpha$ dari LH, FSH dan TSH. Subunit $\beta$ HCG secara struktur hanya sedikit mirip dengan Subunit $\beta$ LH. hCG dan LH berikatan dan berfungsi melalui reseptor $\mathrm{LH}$. Perbedaan utama dari hCG dan LH adalah LH dengan PI 8,0 memiliki waktu paruh di sirkulasi hanya 25-30 menit, sedangkan hCG dengan PI 3,5 waktu paruhnya sampai 37 jam atau 80 kali lebih lama dari LH. hCG adalah super LH yang diproduksi pada saat kehamilan berkerja pada reseptor LH. LH, FSH dan TSH diproduksi di lobus anterior hipofisis, sedangkan hCG diproduksi dengan fusi dan diferensiasi sel sinsitiotropoblas plasenta. ${ }^{13}$ Selain selama kehamilan, hCG juga diproduksi baik pada wanita maupun pria yang menderita kanker. ${ }^{10}$

Pada saat kehamilan, hCG mengambil alih LH dalam menstimulasi produksi progesteron oleh sel korpus luteum ovarium, mencegah perdarahan. Seperti yang kita ketahui sekarang, hCG hanya menstimulasi produksi progesteron pada 3-4 minggu setelah implantasi, artinya hCG hanya berfungsi pada $10 \%$ durasi lama kehamilan. Namun ternyata hCG mencapai puncaknya pada minggu ke 10 kehamilan atau hampir 1 bulan setelah promosi progesteron selesai lalu secara terus menerus diproduksi selama kehamilan. Hal ini menunjukkan bahwa fungsi utama hCG bukanlah produksi progesteron, melainkan memiliki berbagai macam fungsi yang dapat bekerja pada plasenta, uterus dan kemungkinan pada fetus selama kehamilan. ${ }^{13}$

$\alpha$-subunit dari gonadotropin disandi oleh gen CGA, terdiri dari 92 asam amino residu. Sedangkan $\beta$-subunit LH, FSH dan hCG masing-masing terdiri dari 121, 110, dan 145 asam amino (aa) secara berurutan (Gambar 2). Tambahan 
pada panjang $\beta$-subunit hCG akibat pada pemanjangan ujung karbosilnya ada mutasi frameshift dari gen LH- $\beta$ pendahulu. Pemanjangan asam amino ini disebut dengan carboxyl terminal peptide (CTP). ${ }^{14}$ Target untuk pengembangan kontrasepsi vaksin pada hCG ini adalah pada $\beta$-subunit hCG secara utuh ataupun pada CTP dari $\beta$ subunit hCG, hal ini untuk menghindari reaksi silang dengan $\mathrm{LH} .{ }^{4}$

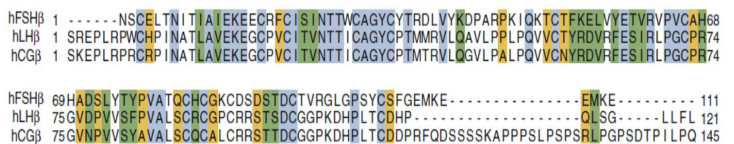

hLG 75 GVNPVVSYAVALSCQCALCRRSTTDCGGPKDHPLITCDDPRFODSSSSKAPPPSLPSPSRLPGPSDTPI LPQ 145

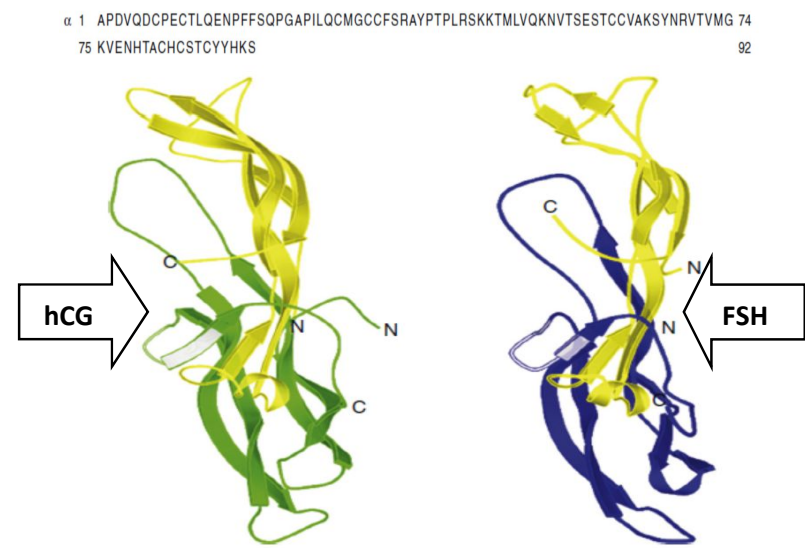

Gambar 2. Struktur asam amino dan 3 dimensi hCG. ${ }^{14}$ Keterangan: kuning: $\alpha$-subunit, Hijau: $\beta$-subunit hCG, biru: $\beta$-subunit FSH

\section{Vaksin kontrasepsi dengan hCG CTP $\beta$-hCG + Difteri Toxoid (DT)}

Imunisasi baboon betina dengan CTP $\beta$-hCG yang dikonjugasikan dengan DT dilaporkan dapat mengurangi fertilitas. Setelahnya, dilakukan uji klini fase I oleh tim vaksin untuk pengaturan fertilitas WHO. Vaksin yang digunakan dalam uji klinis ini adalah sintetik CTP $\beta$-hCG (residu aa ke 109-145) setiap 6 minggu kepada 30 wanita yang telah menjalani sterilisasi dengan ligasi tuba di Bedford Park, Australia. Setelah diikuti selama 6 bulan, tidak ditemukan reaksi efek samping yang penting pada subjek. Pada kelompok wanita yang diimunisasi dengan dosis yang tertinggi ditemukan level antibodi terhadap hCG yang optimal. Untuk memperkuat uji klinis fase I, WHO menginisiasi uji klinis fase II dilakukan di Swedia, namun dihentikan karena adanya efek samping yang tidak dapat diterima pada subjek. ${ }^{4}$ Vaksin ini bereaksi silang dengan somatostatin yang dihasilkan oleh pankreas. ${ }^{15}$

Formulasi baru dengan inkorporasi polylactic-co-glycolic pada CTP menunjukkan harapan yang baik untuk menginduksi epitop sel T dari tetanus toxoid (TT) untuk meningkatkan imunogenisitas CTP sintetik. CTP dari $\beta$-hCG yang dipakai adalah dari asam amino residu ke 111-145. Formula ini menunjukkan respon antibodi yang kuat saat diinjeksikan pada kelinci dengan durasi yang sama dan dicapai setelah injeksi yang ketiga. Injeksi ini diberikan bersamaan dengan emulsi air-squalene di dalam minyak. ${ }^{4}$
Rock et al. (1996) membuat suatu protein fusi antara E. coli heat-labile enterotoxin subunit $B$ (LTB) dihubungkan dengan CTP dari $\beta$ HCG. LBT-CTP secara stabl diekspresikan oleh bakteri tersebut dan membentuk pentamers. Hasil purifikasi protein LTB-CTP tadi dapat menginduksi antibodi spesifik hCG pada tikus tanpa ada adjuvant lain. Tidak ada publikasi setelahnya yang tersedia dalam hal efektivitas vaksin ini. Cara lain untuk meningkatkan imunogenisitas vaksin ini adalah disampaikan oleh Kvirkvelia et al. (2003) dengan menggunakan partikel antigen $\beta$-core dari virus hepatitis sebagai rangkanya. ${ }^{11]}$

\section{B-hCG-TT}

Vaksin hCG adalah yang pertama dan satu-satunya vaksin untuk kontrol fertilitas yang melalui uji klinis fase II dan telah menunjukkan pencegahan kehamilan pada wanita yang aktif secara seksual. ${ }^{16}$ Vaksin ini memiliki efektifitas tinggi dan hanya terjadi satu kehamilan pada penelitian selama 1224 siklus selama titer antibodi tetap $>50 \mathrm{ng} / \mathrm{ml}$. Vaksin ini dilaporkan memiliki reversibilitas yang tinggi dan konsepsi dapat terjadi saat antibodi turun $<35 \mathrm{ng} / \mathrm{ml}$. Yang menarik dari vaksin ini adalah bekerja secara langsung pada molekul hCG yang hanya dapat diproduksi dalam keadaan normal pada wanita hamil. Vaksin ini tidak menimbulkan efek samping, yang dapat dilihat dari hasil uji klinis fase I dan II pada lebih dari 200 wanita. Subjek masih dapat mengalami ovulasi, memproduksi hormon steroid sex secara normal, dan siklus menstruasi tetap teratur serta tidak ditemukan perdarahan yang irreguler seperti flek-flek, amenorrhea atai perdarahan tambahan. ${ }^{17}$ Fase luteal pada wanita yang mendapat vaksin ini tidak mengalami pemanjangan durasi yang mengkonfirmasi penelitian sebelumnya pada monyet yang diberi antibodi anti-hCG untuk mencegah terjadinya implantasi embrio ke dalam endometrium. ${ }^{15}$

Vaksin harus memiliki efektivitas sebesar $>90-95 \%$. Pada vaksin ini masih menunjukkan angka $60-80 \%$. Oleh karena itu, pada saat itu diperlukan suatu studi untuk meningkat imunogenisitas, yaitu dengan menambahakan adjuvan seperti tetanus toxoid (TT) atau difteri toxoid (DT). Penambahan adjuvan ini terbukti meningkatkan imunogenisitas. Peneliti melaporkan bahwa antibodi $\beta$ hCG yang dikonjugasikan dengan TT memiliki kapasitasi bionetralisasi hCG yang sama dengan vaksin CTP $\beta$-hCG. Setelah berbagai studi imunogenisitas dan keamanan vaksin ini pada beberapa model termasuk primata, vaksin $\beta$-hCG+TT menjalani uji klinis fase I di India, Helsinki, Uppsala, Bahia dan Santiago. Penelitian tersebut melaporkan bahwa vaksin ini imunogenik dan aman, namun titer antibodinya bervariasi pada beberapa wanita, sebagian besar subjek menunjukkan titer antibodi yang rendah. ${ }^{4}$ Oleh karena itu, beberapa penelitian sedang mencoba mengganti TT atau TT pada vaksin ini dengan peptida epitop dari sel B non T, protein dari virus measles, protein reverse trancriptase HIV-1 dan hemaglutinin virus influenza. Pemberian konjugasi ini pada tikus dilaporkan meningkatkan imunogenisitas pada berbagai strain tikus. ${ }^{15}$ 


\section{$\beta$-hCG- $\alpha$-oLH-TT/ $\beta$-hCG- $\alpha$-oLH- DT}

Walaupun konjugasi $\beta$-hCG dengan TT sukses menginduksi respon antibodi, namun titer antibodinya rendah pada tiga dari empat subjek. Untuk meningkat imunogenisitasny dilakukanlah dimerisasi $\beta$-hCG dengan $\alpha$-subunit dari LH babi dengan pemikiran bahwa protein dari babi ini dapat meningkatkan antigenisitasnya. Vaksin ini disebut juga dengan heterospescies dimer (HSD) dari $\beta$-hCG dan $\alpha$ subunit LH babi, selanjutnya dihubungkan dengan TT dan DT. Setelah menunjukkan imunogenisitas dan keamanan pada berbagai hewan coba, uji klinis fase II dilakukan pada wanita subur pada beberapa tempat di India. Imunisasi aktif dengan vaksin ini menunjukkan antobodi netralisasi hCG. Kapasitas netrasilsasi ini dihitung dengan pemeriksaan receptor binding inhibition assay, dilaporkan antibodi bionetralisasi hCG terjadi pada titer diatas 50ng/ml. HSD-TT terbukti lebih imunogenik dibandingkan dengan $\beta$-hCG-TT. Selain itu, HSD-TT menginduksi antibodi yang memiliki bioefektivitas yang lebih baik dari $\beta$-hCG-TT. Vaksin ini juga secara keseluruhan tidak bereaksi silang dengan LH manusia, hanya bereaksi secara parsial namun tidak menganggu ovulasi. ${ }^{4}$

Beberapa penelitian di atas juga belum dapat meningkatkan imunogenesitas dan gagal menginduksi titer antibodi diatas $50 \mathrm{ng} / \mathrm{ml}$ pada $100 \%$ subjek. Untuk mengatasi hambatan ketergantungan terhadap ketersedian purifikasi protein $\beta$-hCG dari urin wanita hamil dan lebih meningkatkan imunogenisitas dilakukan fusi protein rekombinan yang terdiri dari $\beta$-subunit dari E. Coli heat-labile enterotoxin dan $\beta$-hCG yang diekspresikan di Pichia pastoris. Protein fusi ini diserap pada Alhydrogel dan digunakan ke Mycobacterium indicus pranii untuk menghasilkan titer $100 \%$ antibodi anti-hCG pada model hewan. Titer antibodi terjadi pada berbagai strain tikus dan angkanya lebih itnggi dari 50ng/ml. Penelitian lebih lanjut sedang dilakukan pada imunogenisitas dan efektivitas vaksin ini pada wanita. ${ }^{4}$

\section{SIMPULAN}

Metode kontrasepsi yang ada sekarang belum dapat menekan angka fertilitas dan memiliki angka kegagalan cukup tinggi, yang terbukti dengan adanya kehamilan yang tidak diinginkan pada pasangan yang menggunakan salah satu metode kontrasepsi di dunia. Kontrasepsi vaksin menjadi pilihan yang menarik dan menjanjikan untuk mencapai tujuan menekan pertumbuhan populasi terutama di negara berkembang. Kontrol pertumbuhan populasi pada akhirnya bertujuan untuk meningkatkan kesejahteraan dan kesehatan.

Ada tiga targe utama kontrasepsi vaksin; yaitu (1) produksi gamet dengan memberikan vaksin aktif maupun pasif untuk menargetkan GnRH, LH dan FSH, (2) fungsi gamet dengan menargetkan protein spesifik sprematozoa dan ZP, (3) hasil gamet berupa embrio dengan menargetkan pada protein spesifik $\beta$-hCG. Vaksin terhadap hCG pada wanita merupakan yang pertama dan satu-satunya metode kontrasepsi vaksin yang telah melalui uji klinis fase ॥ dibandingkan dari dua target lainnya.

hCG diproduksi pada waktu awal setelah fertilisasi dan mempunyai peran penting dlam implantasi pada awal kehamilan. Oleh karena itu, hCG merupakan target potensial dan terbaik dalam mencegah kehamilan tanpa adanya efek samping yang merugikan. Berbeda dari kontrasepsi steroid yang dapat menghambat ovulasi, metode vaksin hCG tidak menganggu ovulasi dan produksi hormon steorid sex serta tidak menganggu keteraturan siklus menstruasi. $\beta$-subunit dari hCG terdiri dari susunan 145 asam amino. Dibandingkan $\beta$-hLH, $\beta$-hCG ini mempunyai tambahan 30 asam amino yang khas disebut dengan CTP. Baik CTP dari $\beta$-hCG maupun $\beta$-hCGnya sendiri telah digunakan sebagai kandidat imunogen untuk mengembangkan kontrasepsi imunologi.

\section{DAFTAR PUSTAKA}

1. Guo C, Manjili MH, Subjeck JR, Sarkar D, Fisher PB, Wang $X Y$. Therapeutic cancer vaccines: past, present, and future. Advances in cancer research. 2013;119:421-75.

2. Anderson RP, Jabri B. Vaccine against autoimmune disease: antigen-specific immunotherapy. Current opinion in immunology. 2013;25(3):410-7.

3. Kantoff PW, Higano CS, Shore ND, Berger ER, Small EJ, Penson DF, et al. Sipuleucel-T immunotherapy for castration-resistant prostate cancer. The New England journal of medicine. 2010;363(5):411-22.

4. Gupta SK, Shrestha A, Minhas V. Milestones in contraceptive vaccines development and hurdles in their application. Human vaccines \& immunotherapeutics. 2014;10(4):911-25.

5. Current World Population [Internet]. 2017. Available from: http://www.worldometers.info/worldpopulation/.

6. International Data Base [Internet]. 2016. Available from:

https://www.census.gov/population/international/dat a/idb/worldpopgraph.php.

7. WHO/63. News Release 2006. Available from: http://whqlibdoc.who.int/press_release/2006/PR_63. pdf.

8. Sundaram A, Vaughan B, Kost K, Bankole A, Finer L, Singh $S$, et al. Contraceptive Failure in the United States: Estimates from the 2006-2010 National Survey of Family Growth. Perspectives on sexual and reproductive health. 2017;49(1):7-16.

9. Naz RK. Contraceptive vaccines: success, status, and future perspective. American journal of reproductive immunology. 2011;66(1):2-4.

10. Purswani S, Talwar GP. Development of a highly immunogenic recombinant candidate vaccine against human chorionic gonadotropin. Vaccine. 2011;29(12):2341-8. 
11. Talwar GP, Nand KN, Gupta JC, Bandivdekar AH, Sharma RS, Lohiya NK. Current status of a unique vaccine preventing pregnancy. Frontiers in bioscience. 2017;9:321-32.

12. Lekhwani S, Vaswani N, Ghalaut VS, Shanker V, Singh R. Immunocontraceptives: How far from reality? Advanced biomedical research. 2014;3:247.

13. Cole LA. Biological functions of hCG and hCG-related molecules. Reproductive biology and endocrinology : RB\&E. 2010;8:102.

14. Ascoli $M$, Narayan P. The gonadotropin hormones and their receptors. In: Strauss JF, Barbieri RL, editors. Yen \& Jaffe's: Reproductive Endocrinology. 7th ed. Philadelphia: Elsevier Saunders; 2014. p. 27-44.

15. Naz RK, Gupta SK, Gupta JC, Vyas HK, Talwar AG. Recent advances in contraceptive vaccine development: a mini-review. Human reproduction. 2005;20(12):3271-83.

16. Talwar GP, Singh O, Pal R, Chatterjee N, Sahai P, Dhall $K$, et al. A vaccine that prevents pregnancy in women. Proceedings of the National Academy of Sciences of the United States of America. 1994;91(18):8532-6.

17. Talwar GP, Singh OM, Gupta SK, Hasnain SE, Pal R, Majumbar SS, et al. The HSD-hCG vaccine prevents pregnancy in women: feasibility study of a reversible safe contraceptive vaccine. American journal of reproductive immunology. 1997;37(2):153-60. 